\title{
How such a small difference can make \\ A big difference
}

The company of kopi luwak has faced many challenges that is related to international marketing like how do we convince that kopi Luwak is also one of the best coffee in the world? how do we fill the high demand by the society?, how do we find the balance between high demand and conservation for the animal? (Aluisius Hery Pratono, Irzameingindra Putri Radjamin, 2012). Back in 2012, The company PT Perkebunan Nusantara XII were being haunted with these questions, it's all the struggles they have to be able to take down in order to make kopi luwak special, but on this paper, since it is limited I will be only focused on the firs one

Kopi Luwak has been mentioned many times in the international scene such as a movie called "bucket list", The Oprah Show mentioning kopi luwak as one of the most expensive coffee in the world, and also Forbes magazine called it as "Number one coffee in the world" (Aluisius Hery Pratono, Irzameingindra Putri Radjamin, 2012). All of this happened because there's a slightly different thing in kopi luwak that doesn't exist in other coffee's where the specialty of kopi luwak is that it is digested by Luwak makes it interesting and people, especially a coffee person, would definitely try this new type of coffee, a different kind of coffee. And that's their main target, For marketing capabilities such as getting more customers, there is evidence that an entrepreneurial orientation should be a determinant of exploration and exploitation (Hamed Mehrabia, Nicole Coviello, Chatura Ranaweera, 2019). Where the company exploits people's behavior of trying something new or something that is currently happening, the comings of kopi luwak as a new comer and unique made it easy for them to gain attention

Brand preference means that the customer tends to choose a brand based on which one they know the most (Keller, 2003). What the people know about kopi luwak is that it is healthier and they think that consuming it is better than normal coffee. And this created a preferable side of luwak where luwak's brand rocket rises because of the perception that the society has.

They have created a really big brand, only by a small difference, but a big difference in process which made people tend to prefer luwak, and has created a great brand for luwak. And that's why it is very important to have a signature on your own, and capitalize it as a your advantage 


\section{REFERENCES}

\section{Bibliography}

Aluisius Hery Pratono, Irzameingindra Putri Radjamin. (2012). Kopy Luwak: a conservation strategy for global. Emerald Emerging Markets Case Studies, 1-5.

Hamed Mehrabia, Nicole Coviello, Chatura Ranaweera. (2019). Ambidextrous marketing capabilities and performance: How and when. Industrial Marketing Management, 129-142.

Keller, K. L. (2003). Strategic Brand Management: Building, measuring, and managing brand. Journal of Business Research. 